\title{
AN ASSESSMENT OF THE VALUE OF HYPNOSIS IN PREGNANCY AND LABOUR*
}

\section{BY}

\section{JOSEPHINE A. DAVIDSON, M.D., F.R.C.O.G. Obstetrician and Gynaecologist, Cumberland Infirmary, Carlisle}

Considerable attention is being paid to the emotional and mental state of women in pregnancy and labour. With modern antenatal care in this country, the physical hazards of pregnancy and labour have been greatly reduced, but the emotional and mental hazards have, if anything. been increased by the high hospital-confinement rate, with the attendant risk of impersonal attention in strange surroundings.

One of many methods of reducing fear and emotional tension in pregnant women is to use hypnosis. The following assessment of its effect on 70 pregnant women was done with two main purposes: (1) To make the patient enjoy her pregnancy and labour; (2) to assess the effect, if any, of mental and physical relaxation on the course of labour, particularly with regard to the duration of labour and the need for chemical analgesia. The 70 women were taught autohypnosis in pregnancy, and the subjective sensations and objective findings in this group were compared with 70 patients taught physiotherapy relaxation by exercises and controlled breathing. and 70 control patients with no special antenatal training. In all three groups 45 were primigravidae and 25 multigravidae. The patients were allowed to choose which group they joined, but the elderly primigravidae, the anxious, and those who had had previously distressing labours were encouraged to join the autohypnosis group, so that this group was weighted with those one would expect to have a difficult or long labour.

The antenatal training consisted of six "lessons" in the autohypnosis and physiotherapy relaxation groups. The patient to be taught autohypnosis attended her first class as soon as possible after her first antenatal visit, the last lesson being as near the time of confinement as possible. The technique employed was as follows. Groups of six patients were taken together, lying on mattresses in a light, warm, quiet room in the hospital. An explanation of the technique was given and questions answered. The obstetrician was the hypnotist. A trance was induced by the method of eye-fixation to produce retinal fatigue, and progressive relaxation by voicesuggestion using monotonous rhythm, and post-hypnotic suggestion as described by Mason (1960). Positive suggestions were then given of the normality of pregnancy and labour, of the diminished awareness of pain when relaxed and therefore of the diminished need for chemical analgesics, and of the ability to produce anaesthesia of the perineum at the birth of the head; also, the satisfaction and pleasure of childbirth was stressed. The patient was then awakened by counting five with suggestions of wakening and feeling refreshed. At the third session the patient was taught to put herself into a trance. so that she would be independent of the hypnotist in the labour ward, although the best results were achieved if the obstetrician-hypnotist could also

* Part of a thesis accepted for the M.D. by Edinburgh University, 1961 attend the labour at the beginning and at the end of the first and second stages. At the postnatal visit the patient was again put into a trance and told that she would only be able to be hypnotized in future by a doctor or dentist for medical purposes, thus protecting the trained subject.

The physiotherapy group were given six weekly relaxation classes of controlled breathing. and pelvic exercises from the 34 th week, by a physiotherapist or midwife. The third control group had no special antenatal training apart from mothercraft classes. All were delivered in the same hospital and under the same conditions.

\section{Results}

The labours of the 45 primigravidae in each group were compared and the following data obtained (Table I).

\begin{tabular}{|c|c|c|c|c|}
\hline Group & $\begin{array}{c}\text { Average } \\
\text { Age }\end{array}$ & $\begin{array}{l}\text { Average } \\
\text { Length of } \\
\text { of } \\
\text { Labour }\end{array}$ & $\begin{array}{c}\text { Average } \\
\text { Blood } \\
\text { Loss in } \\
\text { 3rd Stage }\end{array}$ & $\begin{array}{c}\text { Average } \\
\text { Weight } \\
\text { of } \\
\text { Baby }\end{array}$ \\
\hline Autohypnosis & $\begin{array}{l}\text { yrs. mths. } \\
28\end{array}$ & $\begin{array}{l}\text { hrs. mins. } \\
10 \quad 11\end{array}$ & \multirow{3}{*}{$\begin{array}{c}9 \mathrm{oz} . \\
(255 \mathrm{~g} .) \\
8.8 \mathrm{oz} . \\
(249 \mathrm{~g} .) \\
11 \mathrm{oz} . \\
(312 \mathrm{~g} .)\end{array}$} & \multirow{3}{*}{$\begin{array}{l}7 \mathrm{lb} .2 \mathrm{oz} . \\
(3,232 \mathrm{~g} .) \\
7 \mathrm{lb} .5 \mathrm{oz} . \\
(3,317 \mathrm{~g} .) \\
71 \mathrm{~b} .3 \mathrm{oz} . \\
(3,260 \mathrm{~g} .)\end{array}$} \\
\hline Physiotherapy & 23 & 30 & & \\
\hline Control & 22 & 52 & & \\
\hline
\end{tabular}

When the total time of labour is broken down into the duration of the first, second, and third stages, all the reduction of time in the hypnosis group is found in the first stage (Table II).

\begin{tabular}{|c|c|c|c|c|}
\hline Group & $\begin{array}{l}\text { Average } \\
\text { Duration of } \\
\text { 1st Stage }\end{array}$ & $\begin{array}{c}\text { Average } \\
\text { Duration of } \\
\text { 2nd Stage }\end{array}$ & $\begin{array}{c}\text { Average } \\
\text { Duration } \\
\text { of } \\
\text { 3rd } \\
\text { Stage }\end{array}$ & $\begin{array}{l}\text { Average Total } \\
\text { Length of } \\
\text { Labour }\end{array}$ \\
\hline $\begin{array}{l}\text { Autohypnosis } \\
\text { Physiotherapy } \\
\text { Control } \quad \text {.. }\end{array}$ & 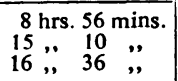 & $\begin{array}{l}1 \text { hr. } 3 \text { mins. } \\
1, " 7 \%, \\
1, " 3 \Rightarrow\end{array}$ & $\begin{array}{l}12 \text { mins. } \\
13 ", \\
13 ",\end{array}$ & $\begin{array}{l}10 \text { hrs. } 11 \text { mins. } \\
16,, 30 \text {," } \\
17,52 \text { ", }\end{array}$ \\
\hline
\end{tabular}

If the length of the first stage of labour is grouped as in Table III the reduction of the duration in the hypnosis group is clearly seen. Thus the hypnosis group, although an older age-group by five years, and selected because of fear and anxiety, had a labour of

\begin{tabular}{c|c|c|c}
\multicolumn{3}{|c|}{ TABLE III } \\
\hline $\begin{array}{c}\text { Length of 1st } \\
\text { Stage of } \\
\text { Labour (Hrs.) }\end{array}$ & $\begin{array}{c}\text { Autohypnosis } \\
\text { Group }\end{array}$ & $\begin{array}{c}\text { Physiotherapy } \\
\text { Group }\end{array}$ & $\begin{array}{c}\text { Control } \\
\text { Group }\end{array}$ \\
\hline $0-6$ & 19 & 7 & 9 \\
$6 \cdot 1-12$ & 19 & 15 & 14 \\
$12 \cdot 1-18$ & 3 & 9 & 6 \\
$18 \cdot 1-24$ & 2 & 7 & 7 \\
$24 \cdot 1-30$ & 2 & 3 & 1 \\
$30 \cdot 1-36$ & 0 & 1 & 1 \\
$36 \cdot 1-42$ & 0 & 2 & 2 \\
$42 \cdot 1-48$ & 0 & 1 & 1 \\
$48 \cdot 1-54$ & 0 & 0 &
\end{tabular}

just over half the average length of the other two groups, the average baby's weight being almost the same in each group. Although this is not a large group the reduction in the duration of labour is statistically significant $(P<0.05)$. This reduction in the length of the labour in patients trained by hypnosis for childbirth and delivered either in the trance state or under posthypnotic suggestion is confirmed by Ahramson and Heron (1950), Michael (1952), and Fry (1959), but not by Winkelstein (1958), August (1960), and Perchard 
child, and of the rest all except two gave their reasons for not wanting another as age or size of family, so that in only two cases did the experience of labour make the patient "not very keen to have another."

This shows a very different picture from that given by the 70 patients with no relaxation training, where four $(6 \%)$ felt no pain or only slight pain in labour ; $33 \%$ described labour as a pleasant sensation, and $24 \%$ found labour unpleasant, and $26 \%$ of those not wanting another child gave the labour as their reason.

In the physiotherapy group trained by Read's method the subjective impressions of the patients in the first stage of labour lie between the autohypnosis group and the controls, but in the second stage physiotherapy

\begin{tabular}{|c|c|c|c|c|c|c|}
\hline \multirow[t]{2}{*}{ Questionary* } & \multicolumn{2}{|c|}{$\begin{array}{l}\text { Hypnosis } \\
\text { Group }\end{array}$} & \multicolumn{2}{|c|}{$\begin{array}{l}\text { Physio- } \\
\text { therapy } \\
\text { Group }\end{array}$} & \multicolumn{2}{|c|}{$\begin{array}{l}\text { Control } \\
\text { Group }\end{array}$} \\
\hline & No. & $\%$ & No. & $\%$ & No. & $\%$ \\
\hline $\begin{array}{l}\text { 1. Memory of (a) The whole of } \\
\text { labour } \\
\text { (b) Part of labour } \\
\text { (c) None ," }\end{array}$ & $\begin{array}{l}33 \\
27 \\
10\end{array}$ & $\begin{array}{l}47 \\
39 \\
14\end{array}$ & $\begin{array}{r}58 \\
10 \\
2\end{array}$ & $\begin{array}{r}83 \\
14 \\
3\end{array}$ & $\begin{array}{r}66 \\
4 \\
0\end{array}$ & $\begin{array}{r}94 \\
6 \\
0\end{array}$ \\
\hline $\begin{array}{l}\text { 2. Pain felt in first stage: } \\
\text { (a) None } \\
\text { (b) Slight } \\
\text { (c) Moderate } \\
\text { (d) Severe }\end{array}$ & $\begin{array}{r}32 \\
22 \\
12 \\
4\end{array}$ & $\begin{array}{r}46 \\
31 \\
17 \\
6\end{array}$ & $\begin{array}{r}6 \\
25 \\
32 \\
7\end{array}$ & $\begin{array}{r}8 \\
36 \\
46 \\
10\end{array}$ & $\begin{array}{r}3 \\
16 \\
33 \\
18\end{array}$ & $\begin{array}{r}4 \\
23 \\
47 \\
26\end{array}$ \\
\hline 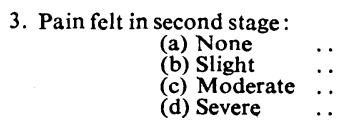 & $\begin{array}{l}17 \\
20 \\
19 \\
14\end{array}$ & $\begin{array}{l}24 \\
29 \\
27 \\
20\end{array}$ & $\begin{array}{r}0 \\
2 \\
19 \\
49\end{array}$ & $\begin{array}{r}0 \\
3 \\
27 \\
70\end{array}$ & $\begin{array}{r}2 \\
2 \\
20 \\
46\end{array}$ & $\begin{array}{r}3 \\
3 \\
29 \\
65\end{array}$ \\
\hline $\begin{array}{l}\text { 4. Was labour (a) Pleasant } \\
\text { (b) Unpleasant } \\
\text { (c) Not sure }\end{array}$ & $\begin{array}{r}49 \\
7 \\
14\end{array}$ & $\begin{array}{l}70 \\
10 \\
20\end{array}$ & $\begin{array}{l}16 \\
24 \\
30\end{array}$ & $\begin{array}{l}23 \\
34 \\
43\end{array}$ & $\begin{array}{l}23 \\
17 \\
30\end{array}$ & $\begin{array}{l}33 \\
24 \\
43\end{array}$ \\
\hline \multicolumn{7}{|l|}{$\begin{array}{l}\text { 5. What about having more } \\
\text { children? }\end{array}$} \\
\hline $\begin{array}{l}\text { Are you (a) Keen } \\
\text { (b) Not keen } \\
\text { (c) Definitely }\end{array}$ & $\begin{array}{r}59 \\
9\end{array}$ & $\begin{array}{l}84 \\
13\end{array}$ & $\begin{array}{l}31 \\
36\end{array}$ & $\begin{array}{l}44 \\
52\end{array}$ & $\begin{array}{l}35 \\
22\end{array}$ & $\begin{array}{l}50 \\
31\end{array}$ \\
\hline against .. & 2 & 3 & 3 & 4 & 13 & 19 \\
\hline $\begin{array}{l}\text { Reasons for } 5 \mathrm{~b} \text { or } \mathrm{c} \text { : } \\
\text { Labour was too unpleasant } \\
\text { Family large enough } \\
\text { Age (over 40) }\end{array}$ & $\begin{array}{l}2 \\
4 \\
7\end{array}$ & $\begin{array}{r}3 \\
6 \\
10\end{array}$ & $\begin{array}{r}14 \\
22 \\
3\end{array}$ & $\begin{array}{r}20 \\
31 \\
4\end{array}$ & $\begin{array}{r}9 \\
23 \\
3\end{array}$ & $\begin{array}{r}13 \\
33 \\
4\end{array}$ \\
\hline
\end{tabular}

* Similar to the questionary used at the Mile End Hospital, London.

training did not appear to alleviate pain or make the labour seem more pleasant to the patient.

Perhaps the greatest subjective gain was that in the autohypnosis group: $70 \%$ described the labour as pleasant, whereas only $23 \%$ of the physiotherapy patients and $33 \%$ of the controls looked back on labour as pleasant.

\section{Summary}

The labours of 70 patients trained in autohypnosis are compared with 70 patients given physiotherapy training for labour and 70 control patients.

A statistically significant reduction in the duration of the first stage of labour occurred in the autohypnosistrained group as compared with the other two groups $(\mathrm{P}<0.001)$.

Autohypnosis was found to be an effective analgesic in labour: $59 \%$ of this group of patients required no chemical analgesia in any stage of labour, whereas in the control group only $1.4 \%$ required no analgesic drug, and in the physiotherapy group all patients required some chemical analgesia. Statistically this difference was very significant $(\mathrm{P}<0.001)$.

No significant difference in the third-stage blood loss was found in the three groups.
The episiotomy or tear rate was less in the hypnotically relaxed patients-51\% as compared with $73 \%$ in the physiotherapy group and $64 \%$ in the control group-but this difference is not statistically significant $(\mathrm{P}=0.10-0.20)$.

The subjective impression of labour was much more pleasant in the autohypnosis group.

The time spent antenatally ( $1 \frac{1}{2}$ hours for six patients) and the personal attention involved are well worth while to produce such objective and subjective benefits to the pregnant woman, and hypnosis should be used in obstetrics more widely than it is at present.

I wish to thank Professor R. Kellar, of Edinburgh, for his help and advice, also Mr. S. Sklaroff, of Edinburgh, for the statistical analysis, and Sister Teasdale, of the City Maternity Hospital, Carlisle, for her co-operation and help in the labour ward.

\section{REFERENCES}

Abramson, M., and Heron, W. T. (1950). Amer. J. Obstet. Gynec., 59, 1069.

August, R.' V. (1960). Ibid., 79, 1131

Burnett, C. W. F. (1956). J. Obstet. Gynaec. Brit. Emp., 63, 40. Fry, A. (1959). Practitioner, 183, 338.

Heardman, H. A. (1954). Reluxation and Exercise for Natural Childbirth, 1st ed., p. 114. Livingstone, Edinburgh

Kline, M., and Guze, H. (1955). J. clin. exp. Hypnos., 3, 142.

Kroger, W. S., and DeLee, S. T. (1943). Amer. J. Obstet. Gynec., 46, 655 .

Mason, A. A. (1960). Hypnotism for Medical and Dental Practitioners. Secker and Warburg, London

Michael, A. M (1952). Brit. med. J., 1, 734.

Perchard, S. D. (1960). In A. A. Mason's Hypnotism for Medical and Dental Practitioners, Chapter XI. Secker and Warburg, London.

Read, Grantley Dick (1949). Lancet, 1, 721.

Rodway, H. E. (1y57). J. Obstet. Gynaec. Brit. Emp., 64, 545.

Tom, K. S. (1960). Obstet. and Gynec., 16, 222

Van Eps, L. W. S. (1955). Lancet, 2, 112.

Werner, W. E. (1959). N.Y. St. J. Med., 1561.

Winkelstein, L. B. (1958). Amer. J. Obstet. Gynec., 76, 152.

\section{CHORIONEPITHELIOMA}

\section{A STUDY OF 41 CASES}

\section{BY}

\section{DONALD P. C. CHAN, M.B., F.R.C.S.Ed.} F.R.F.P.S., M.R.C.O.G.

Lecturer in Obstetrics and Gynaecology, Hong Kong University

A chorionepithelioma is a neoplasm consisting of both syncytial and Langhans trophoblasts in varying proportions. Microscopically, columns and sheets of trophoblasts are seen penetrating the muscle and bloodvessels in a lawless manner interspersed with areas of clotted blood. The most important diagnostic sign of chorionepithelioma is complete absence of a villous pattern. Although Acosta-Sison (1949) saw no fewer than 142 cases of chorionepithelioma during 10 years at Manila, Hall (1950) saw only two in 20 years, Hunter and Dockerty (1955) reported 12 cases in 17 years, and Jones (1954) estimated the incidence as 1 in 70,000 deliveries.

From July, 1953, to December, 1961, a period of eight and a half years, 54,555 deliveries were undertaken by the Department of Obstetrics and Gynaecology, Hong Kong University. In the same period 41 cases of chorionepithelioma were encountered, thus giving an incidence of 1 in 1,331 . This relatively high number is misleading and can be explained by the fact that the patients suffering from chorionepithelioma and referred 